TITLE:

\title{
GLIMPSE OF THE BIOLOGY OF ARGONAUTA ARGO LINNAEUS (CEPHALOPODA : OCTOPODIDA) IN THE JAPANESE WATERS
}

$\operatorname{AUTHOR}(S)$ :

Nishimura, Saburo

CITATION:

Nishimura, Saburo. GLIMPSE OF THE BIOLOGY OF ARGONAUTA ARGO LINNAEUS

(CEPHALOPODA : OCTOPODIDA) IN THE JAPANESE WATERS. PUBLICATIONS OF THE SETO MARINE BIOLOGICAL LABORATORY 1968, 16(1): 61-70

\section{ISSUE DATE:}

1968-06-29

URL:

http://hdl.handle.net/2433/175488

RIGHT: 


\title{
GLIMPSE OF THE BIOLOGY OF ARGONAUTA ARGO \\ LINNAEUS (CEPHALOPODA : OCTOPODIDA) IN THE JAPANESE WATERS ${ }^{1)}$
}

\author{
SABURo NISHIMURA \\ Seto Marine Biological Laboratory, Sirahama
}

With 2 Text-figures

Because of their peculiar structure and habit, the pelagic cephalopods of the genus Argonauta, or the so-called paper nautili, have been well familiar to Japanese from the old times as they were so in the ancient China, India, Greece, Rome, etc. Though all the species of the genus are primarily inhabitants of the open sea, they are rarely accessible amidst the ocean. Rather they are found most frequently stranded on shore. The 'shells', secreted in female, have been found in this way and usually treasured as a curiosity or a kind of ornaments or amulets; then, there are rather abundant documents and records reporting the occurrences of Argonauta.

So far, at least the followeng four species have been recorded from the Japanese waters: Argonauta argo Linnaeus ( $?=A$. grandiformis Perry), $A$. hians Solander, $A$. boettgeri Maltzan ( $?=A$. oweni of Dunker 1882 and of Ikeda 1891) and A. nouryi Lorors. Of these, the first is the commonest and known most widely. However, the biological details of this species, even such fundamental aspects as the geographical distribution, seasonal occurrence, reproduction and feeding patterns, in the Japanese waters have not yet been cleared enough. The present paper is prepared to give some clues to the problems mentioned above, basing on the data accumulated in this country so far as well as on those newly obtained by myself.

Acknoxiledgments - - I am grateful to Mr. O. TABETA of the Department of Fisheries, Kyushu University, and to Messrs. H. Fukataki and M. Okiyama of the Japan Sea Regional Fisheries Research Laboratory, Niigata, for their kind informations and advices. My hearty thanks are also due to Mr. T. Yамамото of our laboratory for his generosity in allowing me to avail his important malacological library. Dr. T. Tокıока kindly read the manuscript.

\section{Occurrence Pattern in the Japanese Waters}

Below are given the records of occurrence of Argonauta argo in the Japanese waters, which are arranged in chronological order and with some short comments:

1) Contributions from the Seto Marine Biological Laboratory, No. 487.

Publ. Seto Mar. Biol. Lab., XVI (1), 61-70, 1968. (Article 8) 
"Saikai Zokudan" (1758)2)_Hundreds of Argonauta were ever drifted to the seashore of the province of Tsugaru [the western part of Aomori Prefecture].

"Tanki Manroku" (1832) ${ }^{3}$-Argonauta were seen commonly in the waters around Sado Island and along the province of Echigo [Niigata Pref.], but rarely in the eastern waters of Honshu.

LischKe (1869)-Record in the Loo-Choo Islands.

Dunker (1882)-Record in Tokyo.

Ortmann (1888)-Enoshima, the province of Sagami [Kanagawa Pref.]

Hirase (1907) - The province of Tango [Kyoto Pref.]

Nakamura (1925)-Numerous individuals were washed ashore at Kashiwazaki, Niigata Pref., in December 1922.

ICHIJMA (1927)-Toyama Bay.

SugITANI (1927)-Yayeyama Island; Miyako Island.

Kuroda (1928)-Amami-Oshima.

SASAKI (1929)-The following localities were added newly: Misaki; Oshima, the province of Osumi [Kagoshima Pref.]; the province of Etchû [Toyama Pref.]; Aomori Bay; Iwanai, Hokkaido.

Ohshima (1930)-Hakata Bay and Tomoé Bay, both in northwest Kyushu.

Kikuchi (1931)-Toyama Bay.

Utsuno (1932)-Kagoshima Bay.

YAGURA (1932)-An immense number of Argonauta argo were stranded on the Japan Sea coasts in the provinces of Tango and Tajima [Kyoto and Hyôgo Pref.] in late November 1928.

Kuroda (1933)-Districts of Niyû, Tsuruga, Oniyû and Oi, all in Fukui Prefecture.

TовA (1935)-A large number of individuals were not infrequently drifted to the coast of Noheji District of Aomori Prefecture; the animals occurred also in the sea off Iwate Prefecture in northeast Honshu but more rarely.

Kamita (1938) - Shimane Pref.; the province of Tango [Kyoto Pref.]; Quelpart Island, southwest Korea; Ulchin, east Korea.

Kinoshita (1939) - An individual was caught at Yoichi, southwest Hokkaido, in October 1939.

Катo (1940)-Shimoda, Izu Peninsula.

Takahashi \& OKamoto (1948)-Fukuoka.

Kurata (1952) - A specimen from Izu-Öshima in August 1948.

T. KURODA in KOBAYASH (1954)-Hundreds of Argonauta will happen to be blown together along the open seashore and even in small inlets in the vicinity of Takahama in the province of Wakasa [Fukui Pref.] in autumn and winter when the wind is very strong.

Kawamoto \& Tanabe (1956)--Japan Sea coast of Yamaguchi Prefecture.

Arakawa (1957)-Rather rarely in Yoronjima Island, Kagoshima Pref.

Anon. (1956)-Kita-ura, Yamaguchi Pref.

Tanabe \& Ukawa (1958)-Occasional records on the west coast of Aomori Prefecture around 19201930.

Azuma (1960)-Near Okinoshima, southwest Shikoku.

HaBe \& KIKUChI (1960)-Ushibuka, west Kyushu.

Iwasawa (1962) - Regular occurrence in Ryôtsu Bay of Sado Island in the season from late October to early November, but rather rare around Tassha on the opposite, southwest, coast of the island.

KAmrta (1962)-A large number of Argonauta argo were ever washed ashore at Kolufu-cho, Shimane Pref.

KuвотA (1962)-Awagasaki, the province of Kaga [Ishikawa Pref.]; Takahama, the province of Wakasa [Fukui Pref.]

2) An old Japanese compilation of miscellaneous stories, “斉諧俗談”.

3) An old Japanese compilation of strange stories, “耿奇漫録”. 
Nishimura (1962)-Fishing nets were found entangled with several specimens of Argonauta argo off Niigata in August 1961. Immense numbers of individuals were drifted to some seashores of the area, including Iwafune District and Niigata City in Niigata Prefecture, Uozu and ShinMinato in Toyama Prefecture, etc. in the winter of 1961-62.

Suzukı (1963)-Nezugaseki, Jûri-Zuka and Tobishima Island, all in Yamagata Prefecture.

Horikawa (1964)-Nagasaki; Gotô Islands.

Hashimoto (1965) - Two specimens at Abashiri on the northeast cbaśt of Hokkaido in middle October 1964; another specimen at Yoichi on the southwest coast of Hokkaido in the same autumn.

IKeHARA (1965)-Many individuals in Ryôtsu Bay of Sado Island in late November 1964.

Kamita (1965)-Oki Islands.

K. Nakano in Nishimura (1967) - Argonauta is not rare in every January on the coast near Masuda in Shimane Prefecture.

TABEta \& Tsukahara (1967) - Shingû coast near Fukuoka, frequently in autumn to winter, 1964.

TAKI \& IGARASHI (1967)-Oshoro and Hakodate, both in Hokkaido.

WAKITA (1967)-Enmyôji coast near Ogura, northwest Kyushu.

New localities-Off Ôhata, Aomori Pref., November 1957; Igarashibama coast near Niigata, November to December $1958 ; 37^{\circ} 17^{\prime} \mathrm{N}, 133^{\circ} 36^{\prime} \mathrm{E}$, August $1959^{4}$; Nigata City, December $1959 ; 38^{\circ} 33^{\prime} \mathrm{N}$, $135^{\circ} 40^{\prime}$ E, November 19604); Ayukawa, Fukui Pref., February 19675); Sirahama, Wakayama Pref., date unknown.

The localities of respective records are plotted on the map in Fig. 1, which shows that Argonauta argo is found almost throughout the Japanese Islands from Ryukyu (Loo-Choo) northward to the northeast coast of Hokkaido. However, there is a marked difference in abundance between areas; evidently, the animal occurs much more frequently and abundantly along the Japan Sea coasts than along the Pacific coasts of the islands. Moreover, along the Japan Sea coasts, most of the occurrences are made in winter from November to January, as seen in the notes given above.

Such a pattern of occurrence is very similar to that known for some other oceanic tropical animals such as the leatherback turtle Dermochelys coriacea and the big-finned squid Thysanoteuthis rhombus (Nishrmura 1964, 1966). Without doubt the northwest monsoon prevailing over the Japan Sea from late October to March and the southerly drift currents induced by it must be decidedly influential to the drift and stranding of Argonauta argo along the Japan Sea coast.

On the other hand, the female Argonauta is believed to be normally an inhabitant of the middle layer and come up to the surface only occasionally (КовAYASHI 1954). Then, for the realization of the noteworthy winter stranding of Argonauta along the Japan Sea coast, there must be another mechanism by which the animals are brought up to the sea surface to be directly affected by monsoon winds and surface drift currents.

During the season from autumn to spring in the Japan Sea, it is not rare to observe the formation of the so-called streaks on the sea surface under the wind blowing even when it is weak to moderate. The streaks are usually marked with gathered bubbles or floating Sargassum, or occasionally with dense plankton organisms such as

4) These interesting records made on the open sea were kindly offered me by Mr. H. FUKATAKI of the Japan Sea Regional Fisheries Research Laboratory.

5) Information from the Fukui Municipal Museum. 
Oikopleura (cf. Nishimura 1960). It is explained that the streak formation is due to the systems of helical vortex pairs induced by wind in the surface layer of the sea (Langmuir 1938; Woodcock 1944, 1950; Stommel 1952). Evidently, in the Japan Sea, such helical motions of the surface water will develop on a much prominent scale in the middle of winter, when the monsoon attains its peak and the water is chilled intensively from the surface ${ }^{6}$; not infrequently the atmospheric temperature

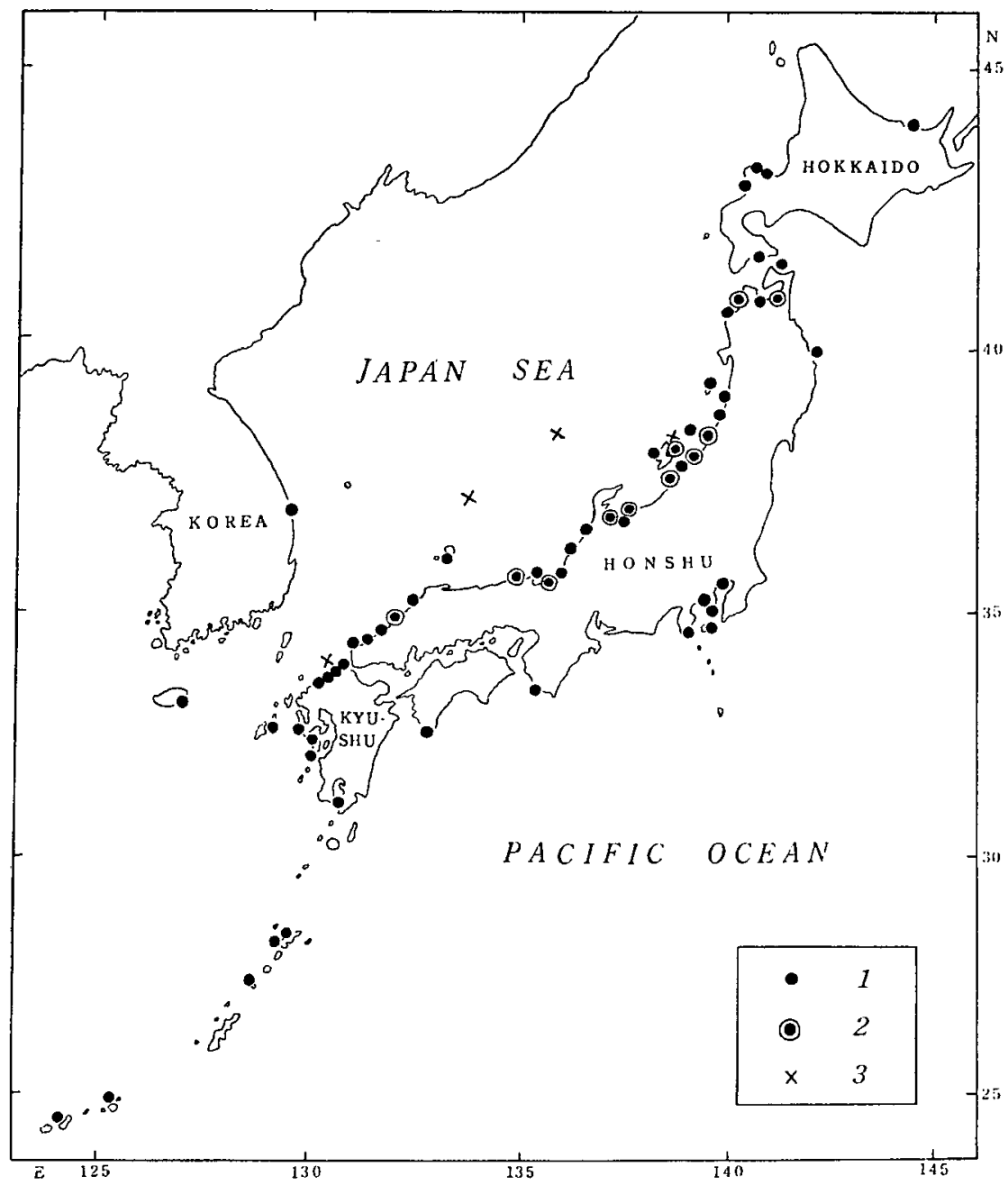

Fig. 1. Distribution of Argonauta argo in the Japanese and adjacent waters. 1-Locality of a single or a few occurrences; 2-Locality of mass occurrences; 3-Occurrence of young females, smaller than $20 \mathrm{~mm}$ in mantle length.

6) Consulting the results of a laboratory experiment made by TERADA (1927), it is estimated (SUzUKI 1951, pp. 190-191) that the helical vortices supposed by LANGMUIR (1938) to be formed in the Sargasso Sea under a mean condition will extend vertically to $25-50 \mathrm{~m}$ deep. 
becomes lower than the surface water temperature by more than $10^{\circ}-15^{\circ} \mathrm{C}$, and the wind of more than 20 knots continues to blow for a long time. Such conditions must be particularly favorable for the formation of a large-scale helical motion of the surface water.

The female Argonauta may happen to go up near to the bottom of the helical vortex system by jetting water from the funnel (cf. Young 1959). They may be then trapped by the helical flow, carried to the converging boundary between the adjoining vortices, and brought up toward the surface by the ascending flow if the flow is strong enough over the sinking of the animal by gravity (Fig. 2, A-B). It is possible, as pointed out by Sтомmel (1949), that the animals may be gradually accumulated in and near the region of the ascending flow. The sea surface must naturally be rough in this

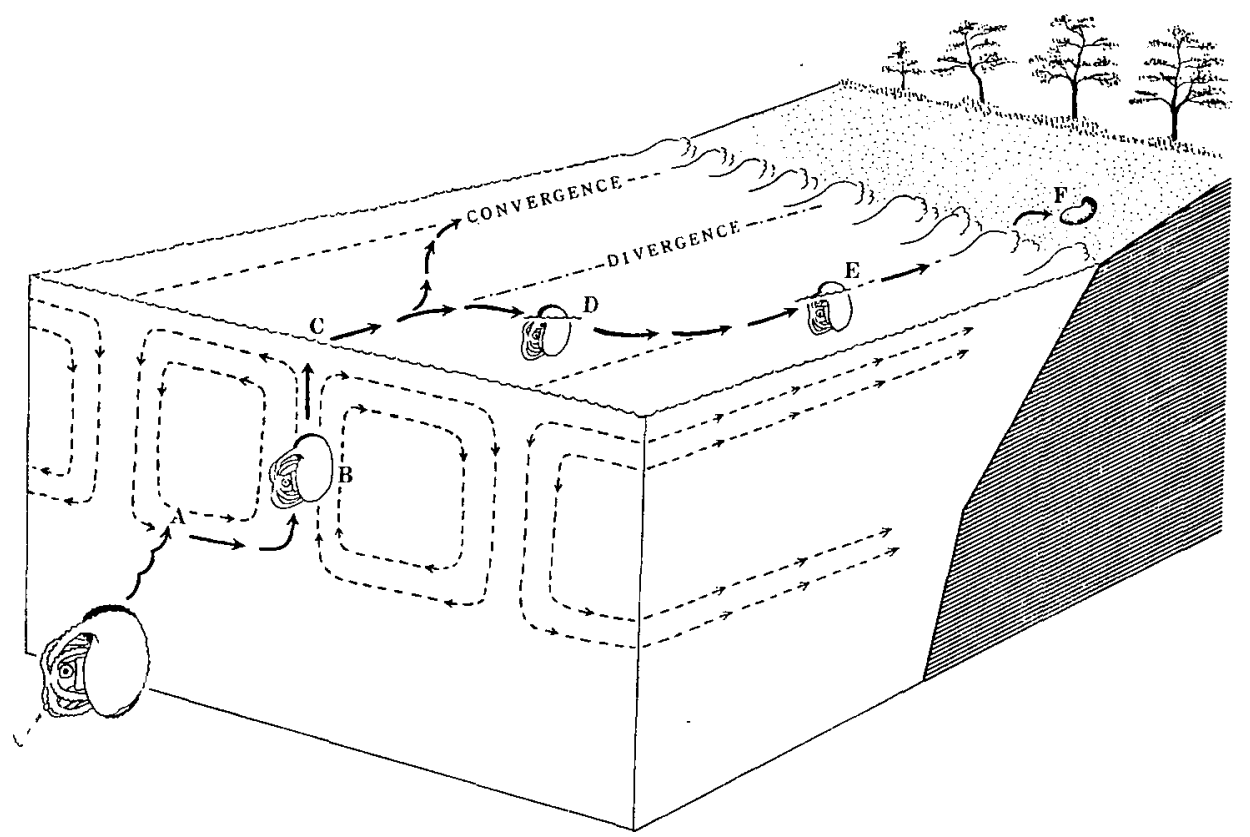

Fig. 2. Schema explaining the supposed mechanism of mass stranding of the female Argonauta on the coast of the Japan Sea. For further explanation, see the text.

season; then, it is very probable that some of the accumulated animals will happen to be exposed to the air on the sea surface and catch air inside the shell. Those animals can no longer sink by themselves nor can be carried down by the descending flow of the water because of a high buoyancy; they will remain on the sea surface, gathering along the convergence streaks ( Fig. 2, C-D-E). In such a process, the female Argonauta floating along the convergence lines will gradually increase in number, and will be driven south- or southeastwarcl in a surprising speed by the monsoon wind and the surface drift current, eventually to be stranded on the west 
coast of Honshu Island in numbers (Fig. 2, F).

On the Pacific side of Japan, on the other hand, the female Argonauta similarly brought up to the sea surface will be transported by the monsoon wind and drift current toward the oceanic central area but never be washed ashore in the winter season. The few records known from this area are mostly made in the warm season of the year.

Though the empty shells are found on the seashore most frequently, it is none the less not uncommon to find the shells harboring a living female which may sometimes be accompanied by a dwarf male. The empty shells in a perfect state found stranded might seemingly hold the live animals till a short time before, as it is suggested by KоваYashi (1954) that the fragile shell will be broken down in pieces sooner or later after it is evacuated.

\section{Breeding Season}

Rather few references are available as to the breeding of Argonaula argo. Lo BIANCo (1909) obtained eggs and embryos in various stages in May to October and young individuals in September to November near Naples. Young (1959) had again at Naples in July two chances of observing the egg laying of this animal in the aquarium. Nothing has, however, been reported as to the breeding in the Japanese waters.

From time to time egg clusters have been found inside the shell of Argonauta argo examined by myself or by some of my acquaintances; the clusters are hanging from the dorsal edge of the whorl. Records of such findings made in the Japanese waters, however, are few as they are listed below:

1. Several living females caught off Niigata by mackerel purse-net in August 1961 were examined by myself and it was found that some of them were incubating.

2. A large number of amimals were washed ashore at Kôdo near Niigata in late November 1961, many individuals of which were found by myself being provided with eggs.

3. An incubating female was caught by set net at Takayama-misaki on the Japan Sea coast of Yamaguchi Prefecture in late May 1962 (personal communication of June 10, 1962, from K. Nakano).

4. Of many females collected in Ryôtsu Bay, Sado Island, in late November 1964, all individuals with the shell longer than $10 \mathrm{~cm}$ were found with eggs in various developmental stages. Hatching out of larvae was also comfirmed (IKEHARA 1965).

5. Many females were stranded on the beach of Shingû near Fukuoka, northwest Kyushu, around the winter of 1964-65, of which the individuals with the shell higher than ca. $5 \mathrm{~cm}$ were all provided with eggs in various developmental stages. Such incubating females were found in October through January (Pcrsonal communication of Fcb. 29, 1968, from O. TABETA).

6. An ovigerous female was caught on the coast of Enmyôji near Ogura, northewst Kyushu, in November 1966 (Wakita 1967).

7. An incubating female was collected on the coast of Ayukawa, Fukui Prefecture, in early February 1967 (Information of March 25, 1967, from the Fukui Municipal Museum).

Thus, the records of incubating females are distributed in January, February, 
May, August and October to December. Since the eggs of Argonauta are much smaller than in typical octopods, the incubation period is considered in all probability not to be so long; then, it seems very likely that the breeding season of this octopod extends almost the year round. Such an extended breeding season does not seem unusual for the pelagic, primarily warm-water animals like the present octopod. IKeHARA (1965) described a wide range of the shell length, 16-204 mm, on the specimens collected in Ryôtsu Bay in late November 1964. It seems to me that all those individuals belong to the same year class and to different hatches in various seasons of the same year rather than to different year classes. It is quite doubtful that Argonauta lives more than a few years.

Although the ovigerous females are found rather frequently in the Japan Sea and its adjacent waters as mentioned above, it is rare to meet with young individuals of Argonauta argo there. In late August 1959, a young female, $12 \mathrm{~mm}$ in mantle length, was caught by surface tow of a large (Maruchi-type) plankton net, and in early November 1961, two more young females, respectively about 10 and $15 \mathrm{~mm}$ in mantle length, were collected in a similar way in the offshore waters of the Japan Sea (personal information of Feb. 8, 1968, from H. FuKaraki; for the exact localities, see the previously given list). O. TABETA informs in his personal letter of Feb. 29, 1968 , that some young females with the shell 15-20 mm high appear in late December to January on the beach of Shingû, northwest Kyushu. IKeHara's (1965) record of young individuals in Ryôtsu Bay in November, one of which was as small as $16 \mathrm{~mm}$ in shell length, may be added here as another datum. Probably, most of these young individuals might have been produced in the waters south of the Japan Sea or in the southern part of the Japan Sea when the water temperature is still high enough in late summer to autumn. Of the larval octopods newly liberated in the Japan Sea, some may escape from this marginal sea to the Pacific through the Tsugaru Straits or to the East China Sea through the Tsushima Straits, but the majority remaining in the Japan Sea may very likely to unable to survive the severe winter condition there. Thus, the population of Argonauta argo found in the Japan Sea is considered to be allogenetic.

\section{Summary}

1. The paper nautilus Argonauta argo is recorded from almost the entire coasts of Japan ranging from the Ryukyu Islands to northeast Hokkaido. May of these records are of the empty shells washed ashore, although living animals are by no means uncommon at least in certain districts.

2. Occurrences are much more frequent and in abundance along the Japan Sea coasts than along the Pacific coasts of the Japanese Islands. The maximal occurrence in the former is found in the season from November through January.

3. The northwest monsoon together with the helical vortex systems and drift 
currents induced by it in the surface layer are supposed responsible for the mass stranding of $A$. argo along the Japan Sea coasts in winter. The same conditions are, however, unfavorable for the stranding of this octopod on the Pacific coasts of Japan.

4. The breeding season seemingly extends for a very long period, perhaps throughout the year. However, it is hardly possible that the newly liberated larvae survive the winter and attain the adult stage in the Japan Sea. The population of Argonauta argo found in the Japan Sea is considered to be allogenetic and recruited there by warm ocean currents from the southerly waters in the Pacific.

\section{REFERENCES}

Arakawa, K. 1957. [A preliminary list of Mollusca of Yoronjima]. Kairui Dôkôkai Kaihô, Kagoshima, vol. 6, nos. 3/4, pp. 1-17. (In Japanese).

Azuma, M. 1960. A catalogue of the shell-bearing Mollusca of Okinoshima, Kashiwajima and the adjacent area (Tosa Province), Shikoku, Japan. Nishinomiya, Kôbe, ix $+102+x v i i$ pp., 5 pls. (In Japanese).

Anonym. 1956. [Peculiar animals and plants of Yamaguchi Prefecture]. Yamaguchi Pref. Office, Education. Sect. (In Japanese).

DUnker, W. 1882. Index Molluscorum Maris Japonici. 301 pp., 16 pls.

HABE, T. \& KiкUCHI, T. 1960. Fauna and flora of the sea around the Amakusa Marine Biological Laboratory, pt. I. Mollusca. Amakusa, Kumamoto Pref., 70 pp. (In Japanese).

Hashimoto, T. 1965. [Correspondence to the editor]. Chiribotan, Tokyo, vol, 3, p. 142. (In Japanese).

Horikawa, Y. 1964. A catalogue of the mollusks of Nagasaki Prefecture. Nagasaki, $x+92+$ iv pp., 1 map. (In Japanese).

Hirase, Y. 1907. [Catalogue of marine shells of Japan to be had of Y. Hirase]. Kyoto, 49 pp., 3 pls. (In Japanese).

Ichiıma, U. 1927. [A list of aquatic animals and plants of Toyama Prefecture, pt. I.] Namerikawa, Toyama Pref., ii +16 pp. (In Japanese).

IKEDA, S. 1893. [A list of Japanese cephalopod specimens deposited at the Science University, pt. III]. Dôbutsugaku Zasshi, vol. 3, pp. 23-30. (In Japanese).

IKEHARA, K. 1965. [Argonauta argo caught in Ryôtsu Bay]. Nihonkai Suisan Shiken Kenkyu Renraku Nyûsu, no. 165, p. 2. (In Japanese).

IWasawa, H. 1962. Marine invertebrates of Kanaizumi coast, Sado Island. Sado Hakubutsukan Kampô, no. 9, pp. 7-13. (In Japanese).

Kamita, T. 1938. [Two additions to the cephalopod fauna of Korea]. Dôbutsugaku Zasshi, vol. 50, pp. 472-473. (In Japanese).

1962. Visits by unusual aquatic animals to the sea coasts of San-in District, Japan Sea. San-in Bunka Kenkyu Kiyô, no. 2, pp. 1-35. (In Japanese).

Japanese).

Kato, K. 1940. [The Mitsui Institute of Marine Biology and the fauna and flora of its vicinity]. Saishu to Shiiku, vol. 2, pp. 167-172. (In Japanese).

Kawamoto, T. \& Tanabe, S. 1956. Catalogue of molluscan shells of Yamaguti Prefecture. Yamaguti, iv $+x+171$ pp., 1 pl. (In Japanese).

Kiкuchi, K. 1931. [Catalogue of the Mollusca of Toyama Bay]. Toyama, 40 pp. (In Japanesc).

Kinoshita, T. 1939. [Three strange animals on the beach near Yoichi]. Hokusuishi Jumpô, no. 444, pp. 227-228. (In Japanese).

KoBAyASHI, T. 1954. Izumonauta, a new genus of the Argonautinae, with a note on their rare but gregarious fossil occurrence. Japan. J. Geol. \& Geogr., vol. 25, pp. 21-34, pls. 3-4.

KuвотA, H. 1962. A catalogue of the molluscan shell specimens in the Fukui Municipal Museum 
(Natural History). Fukui, v+242 pp. (In Japanese).

Kurata, Y. 1953. Molluscan fauna of Ohsima Island, Izu. Saishu to Shiiku, vol. 15, pp. 229-326. (In Japanese).

Kuroda, T. 1928. Catalogue of the shell-bearing Mollusca of Amami-Ôshima (Ôshima, Ôsumi). Kagoshima, vii 126 pp. (In Japanese).

1933. [A catalogue of the molluscan shells of Fukui Prefecture]. Fukui-ken Seibutsu Mokuroku, Fukui, pp. 169-205. (In Japanese).

LANGmuir, I. 1938. Surface motion of water induced by wind. Science, vol. 87, pp. 119-123.

Lischкe, C. E. 1869. Japanische Meeres-Conchylien, Bd. I. 191 pp., 14 pls.

Lo BIANCO, S. 1909. Notizie biologiche riguardanti specialmente il periodo di maturità sessuale degli animali del Golfo di Napoli. Mitt. Zool. Stat. Neapel, Bd. 19, pp. 513-761.

Nakamura, M. 1925. [Natural products of Nigata Prefecture]. Niigata, xi+704 pp., 3 pls. (In Japanese).

Nishimura, S. 1960. [Streaks due to the swarms of Oikopleura]. J. Oceanogr. Soc. Japan, vol. 16, pp. 151-152. (In Japanese).

1962. [An outbreak of the paper nautilus]. Nihonkai Suisan Shiken Kenkyu Renraku Nyûsu, no. 132, p. 2. (In Japanese).

1964. Considerations on the migration of the leatherback turtle, Dernochelys coriacea

(L.), in the Japanese and adjacent waters. Publ. Seto Mar. Biol. Lab., vol. 12, pp. 177-189.

1966. Notes on the occurrence and biology of the oceanic squid, Thysanoteuthis rhombus Troschel, in Japan. Ibid., vol. 14, pp. 327-349.

1967. Occurrence of the paper nautilus, Argonauta argo L., in the Japanese waters. Saishu to Shiiku, vol. 29, pp. 204-205. (In Japanese).

Ortmann, A. S. 1888 . Japanische Cephalopoden. Zool. Jahrb. Abt. System., Bd. 3, pp. 639-670, pls. 20-25.

Oнsнiмa, H. 1930. [Amakusa miscellanies, pt. 3]. Dôbutsugaku Zasshi, vol. 42, pp. 29-37. (In Japanese).

SASAKI, M. 1929. A monograph of the dibranchiate cephalopods of the Japanese and adjacent waters. J. Fac. Agr., Hokkaido Imp. Univ., vol. 20, suppl. number, 357 pp., 30 pls.

Stommel, H. 1949. Trajectories of small bodies sinking slowly through convection cells. J. Mar. Res., vol. 8, pp. 24-29.

1952. Streaks of natural water surfaces. M.I.T. Geophys. Res. Pap., no. 19.

Sugitani, F. 1927. [Catalogue of Loochoo shells]. Okinawa Kyôiku, no. 163, pp. 1-64. (In Japanese). Suzuki, S. 1951. [Agricultural meteorology]. Tokyo, iii +267 pp. (In Japanese).

SuzukI, SH. 1963. Fauna of the coast and the adjacent sea of Shônai. I. Invertebrata. Yamagata, ii +43 pp. (In Japanese).

Tabeta, O. \& Tsukahara, H. 1967. Ecological studies on the fishes stranded upon the beach along the coast of the Tsushima current- - . Fishes and other animals recorded during the first half of 1965 in northern Kyushu. Bull. Japan. Soc. Sci. Fish., vol. 33, pp. 295-302.

Tаканалнi, G. \& Окамото, M. 1948. [A catalogue of molluscan shells from Fukuoka Prefecture]. Fukuoka. (In Japanese).

Taki, Iw. \& Igarashi, T. 1967. A list of cephalopod specimens in the Fisheries Museum, Faculty of Fisheries, Hokkaido University. Contrib. Fish. Mus., Fac. Fish., Hokkaido Univ., no. 7, 27 pp. (In Japanese).

Tanabe, M. \& Ukawa, M. 1958. [On the hydrography and fisheries conditions off Aomori Prefecture]. Tsushima-Danryû Kaihatsu Chôsa Hôkokusho, Tokyo, ser. I, pp. 427-454. (In Japanese).

Terada, T. 1927. Formation of periodic columnar vortices by convection. Proc. Imp. Acad., Tokyo, vol. 3, pp. 503-506.

Toвa, G. 1935. [Talks about the molluscan shells of Tôhoku, pt. 6]. The Venus, vol. 5, pp. 117120. (In Japanese).

Utsuno, SH. 1932. A list of the Cephalopoda of Kagoshima Bay. Ibid., vol. 3, pp. 228-233. (In 
Japanese).

Wakita, O. 1967. [Correspondence to the editor]. Fukui-shi Kyôdo Hakubutsukan Dayori, no. 125, p. l. (In Japanese).

Woodcock, A. H. 1944. A theory of surface water motion deduced from the wind-induced motion. of the Physalia. J. Mar. Res., vol. 5, pp. 196-205.

1950. Subsurface pelagic Sargassum. Ibid., vol. 9; pp. 77-92.

Yagura, W. 1932. [Catalogue of molluscan shells of Hyôgo Prefecture, with appendix of that of Molluscoidea (revised ed.)] Nishinomiya, Kôbe, iv $+63+$ viii pp., 5 (1 col.) pls. (In Japanese).

Young, J. Z. 1959. Observations on Argonauta and especially its method of feeding. Proc. Zool. Soc. London, vol. 133, pp. 471-479, 2 (1 col.) pls. 